\begin{tabular}{|c|l|}
\hline Title & Removal of A rsenic, Boron, and Selenium from Excavated Rocks by Consecutive Washing \\
\hline Author(s) & Tabelin, Carlito Baltazar; Basri, A mir Hamzah Mohd; Igarashi, Toshifumi; Y oneda, Tetsuro \\
\hline Citation & $\begin{array}{l}\text { Water, A ir, \& Soil Pollution, 223/7), 4153-4167 } \\
\text { https://doi.org/40.1007/311270-012-1181-x }\end{array}$ \\
\hline Issue Date & 2012-09 \\
\hline Doc URL & http://hdl.handle.net/2115/50286 \\
\hline Rights & The final publication is available at www.springerlink.com \\
\hline Type & article (author version) \\
\hline File Information & WA SP223 7_4153-4167.pdf \\
\hline
\end{tabular}

Instructions for use 


\title{
Removal of arsenic, boron and selenium from excavated rocks by consecutive washing
}

\author{
Carlito Baltazar Tabelin**1, Amir Hamzah Mohd Basri ${ }^{2}$, Toshifumi Igarashi ${ }^{3}$ and Tetsuro \\ Yoneda $^{1}$ \\ ${ }^{1}$ Laboratory of Soil Environment Engineering, Faculty of Engineering, Hokkaido University, Sapporo 060-8628, \\ JAPAN \\ ${ }^{2}$ Toyo Engineering and Construction Sdn. Bhd., Kuala Lumpur 50250, MALAYSIA \\ ${ }^{3}$ Laboratory of Groundwater and Mass Transport, Faculty of Engineering, Hokkaido University, Sapporo 060-8628, \\ JAPAN \\ E-mails: carlito@trans-er.eng.hokudai.ac.jp, amirhamzah@ga.toyo-eng.co.jp, tosifumi@eng.hokudai.ac.jp and \\ yonet@eng.hokudai.ac.jp
}

\begin{abstract}
This paper describes the leaching behavior and release mechanisms of arsenic (As), boron (B) and selenium (Se) from excavated rocks using sequential extraction for solid-phase fractionation, batch experiments with $\mathrm{pH}$ variation, and consecutive batch experiments with changes in the solid-liquid mixing ratios. Arsenic in the excavated rock was mostly found with the sulfides/organic matter fraction while majority of the leachable B and Se were associated with the exchangeable phases. The leaching of As was strongly $\mathrm{pH}$ dependent, Se was $\mathrm{pH}$ dependent only around the acidic region, and $\mathrm{B}$ was $\mathrm{pH}$ independent. Consecutive washing technique with deionized water effectively lowered the B and Se concentrations in the leachate below the drinking water standards of Japan, but was inefficient in the removal of As. Arsenic exhibited non-conservative leaching behavior and its movement was affected by processes like dissolution, precipitation and pyrite oxidation. In contrast, B and Se behaved more conservatively, resulting in their easy removal from the excavated rock by simple washing and dilution.
\end{abstract}

Keywords: Arsenic, boron, selenium, excavated rocks, washing

*Corresponding author: Tel: +81-11-706-6311 Fax: +81-11-706-6308

email: carlito@trans-er.eng.hokudai.ac.jp 


\section{INTRODUCTION}

Recent tunnel projects in Japan for roads, railways and other purposes have excavated rocks containing significant amounts of arsenic (As), boron (B), selenium (Se) and heavy metals. These hazardous excavated rocks generally fall into two categories: altered and sedimentary rocks. Excavated rocks that have undergone hydrothermal alteration are usually enriched with As and heavy metals. On the other hand, unaltered sedimentary rocks generally contain significant amounts of As, B and Se that originate from the sea during the diagenesis of the rock. Arsenic is toxic even in minute amounts and can cause serious health problems like arsenicosis, keratosis and certain types of cancer (O'Day et al. 2004; Sengupta 2002). Boron and Se are essential micronutrients but toxic at high concentrations. Large doses of the former could cause reproductive and developmental problems (Fail et al. 1998) while the latter could cause selenosis in humans and animals (Tinggi 2003). Disposing such hazardous construction wastes into the environment, without any proper treatment to reduce their risks, would pollute the surrounding areas as well as harm all living organisms through the food chain. Special landfills are currently used for the disposal of these rocks, but this approach is very expensive and not viable in the long term due to the huge amount of excavated rocks produced annually. Thus, a more costeffective disposal method that can adequately detoxify the waste material needs to be developed.

Published works regarding the distribution and mobilization of As, B and Se in the environment especially in aquifer and soil systems are numerous (Acharyya et al. 2000; Akai $e t$ al. 2004; Brannon and Patrick 1987; Das et al. 1996; Dowling et al. 2002; Fishbein 1983; Levinson and Ludwick 1966; Parks and Edwards 2009; Peters and Blum 2003; Savage et al. 2000; Zawislanski et al. 2003). In addition, hydrothermally altered rocks have been extensively covered in the literature particularly in the context of ore formation and characterization (Aiuppa 
et al. 2006; Allen and Hahn 1994; Halbach et al. 1993; Horton et al. 2001; Huston et al. 1995; Ostwald and England 1977). However, very few have tackled the problem associated with toxic element release from excavated rocks. Our previously published works have explained the importance of $\mathrm{pH}$, redox potential (Eh) and dissolved oxygen (DO) in the leaching behaviors of As and $\mathrm{Pb}$ from altered rocks and the strong influence of minor or trace minerals like pyrite and calcite on the mechanisms controlling their release (Tabelin and Igarashi 2009; Tabelin et al. 2010; Tabelin et al. 2012a). Furthermore, results of long-term column experiments by the authors showed that a considerable amount of As in altered rocks was released during the early stages via the dissolution of soluble secondary minerals, which were mostly products of pyrite oxidation (Tabelin et al. 2012b). Based on these previous results, it seems that the removal of these soluble secondary phases may potentially solve the problem of toxic elements release from excavated rocks.

This study was conducted to examine the effectiveness of "washing" as a mitigation approach for excavated rocks containing toxic elements. The hazardous elements of concern in this research include As, B and Se. Consecutive batch leaching experiments were conducted to simulate the washing process. The effects of solid-liquid ratio on the leaching behaviors of these hazardous elements were also elucidated. Furthermore, the effects of $\mathrm{pH}$ and coexisting ions on the leaching behaviors of B and Se were investigated because these elements were not included in our previous papers. Finally, sequential extraction was conducted to identify the functional solid phases of the excavated rocks that incorporate these elements. If successful, washing could be an effective and economical mitigation approach for these types of rocks. Findings of this study may to some extent address the current environmental pollution problems related to the leaching of toxic elements, particularly As, from sedimentary and hydrothermally altered rocks excavated during tunnel construction. 


\section{MATERIALS AND METHODS}

\subsection{Sample collection, preparation and characterization}

Four rock samples were collected from different tunnel construction projects in the island of Hokkaido, Japan. Rock samples collected from Nakakoshi (N sample), Teine (T sample) and Sensyo (S sample) are hydrothermally altered rocks while that from Horonobe (H sample) is an unaltered sedimentary rock. The $\mathrm{N}$ sample is mostly composed of slate that underwent hydrothermal alteration characterized by silicification, pyritization and argillic alteration of kaolinite resulting in high As abundances in the rock (up to $510 \mathrm{mg} / \mathrm{kg}$ ) (Tabelin et al. 2012b). The T sample was collected from a closed mine site with epithermal Au-Ag-Cu deposit and is mostly composed of altered tuff and andesite (Tabelin et al. 2012a). The rock sample collected from the $\mathrm{S}$ site is composed mainly of partly altered mudstone and sandstone formed during the Cretaceous period (Tabelin et al. 2012a). The sedimentary rock sample from the $\mathrm{H}$ site is composed predominantly of mudstone rich in diatoms. During the construction of these tunnels, excavated rocks were temporarily stored at interim sites prior to their final disposal. Sampling was done at random points at these sites using a shovel. Sizes of the rocks collected ranged from big (ca. $20 \mathrm{~cm}$ in diameter) to fine $(<2 \mathrm{~mm}$ in diameter). These rock samples were brought back to the laboratory, air dried, crushed, sieved through a $2 \mathrm{~mm}$ aperture screen and stored in air tight containers to minimize exposure to moisture. The effect of sample variability was kept to a minimum by crushing all rocks collected from each site to $<2 \mathrm{~mm}$, mixing them thoroughly and storing them in one container. Moreover, mixing of the crushed rock was always done in these containers before sampling for the subsequent experiments. Samples used for both the leaching and sequential extraction experiments were taken from these "stock" crushed rocks. For the chemical and mineralogical analyses, samples taken from the "stock" containers were further 
crushed to less than $50 \mu \mathrm{m}$ and then analyzed using an X-ray fluorescence spectrometer (Spectro Xepos, Rigaku Corporation, Japan) and an X-ray diffractometer (MultiFlex, Rigaku Corporation, Japan), respectively. Boron and Se contents of the excavated rock samples were determined using the wet method, which was done by total dissolution of the sample with strong acids and subsequent analysis of the leachate.

\subsection{Sequential extraction experiments}

The sequential extraction procedure used in this study was developed by Marumo et al. (2003) for the determination of the leachabilities of trace elements including As from soils and sediments. This method was a modification of the procedures of Tessier et al. (1979) and Clevenger (1990). A summary of the extraction procedure used is outlined in Table 1. For this procedure, one gram of the $<2 \mathrm{~mm}$ crushed rock fraction was utilized. After each extraction step, the residue was washed with $8-10 \mathrm{ml}$ deionized (DI) water $(18 \Omega \cdot \mathrm{cm})$ and diluted to $50 \mathrm{ml}$ prior to the chemical analysis. The residual fraction was calculated from the difference between the total amount of As and the total As extracted from the sample.

\subsection{Batch leaching experiments with $\mathrm{pH}$ variations}

Batch leaching experiments were conducted by mixing 15 grams of crushed rock sample with $150 \mathrm{ml}$ of prepared leachant with known concentrations of acid or base for 24 hours at $120 \mathrm{rpm}$. The desired suspension $\mathrm{pH}$ values were achieved by adding reagent grade hydrochloric acid $(\mathrm{HCl})$ or sodium hydroxide $(\mathrm{NaOH})$ solutions (Wako Pure Chemical Industries Ltd., Japan). After 24 hours, the $\mathrm{pH}$ and Eh of the suspensions were measured and the leachates collected by filtration through $0.45 \mu \mathrm{m}$ sterile membrane filters (Millipore Corporation, USA). The leachate samples were then stored at $6^{0} \mathrm{C}$ prior to the chemical analyses. 


\subsection{Consecutive leaching experiments}

Consecutive batch leaching experiments were conducted with different solid-liquid ratios. Rock samples with mass of 10, 20 and $50 \mathrm{~g}$ were mixed separately with $100 \mathrm{ml}$ of DI water, which is equivalent to solid-liquid ratio of 1:10, 1:5 and 1:2, respectively. The rock-DI water suspensions were shaken at $120 \mathrm{rpm}$ for 24 hours. After shaking, the $\mathrm{pH}$, Eh and electrical conductivity (EC) were measured followed by centrifugation of the suspension using Sigma 3K 30 laboratory centrifuge (Sigma, Germany) for 30 minutes at a speed of 3,000 rpm. The supernatant was then filtered using vacuum filtration with $0.45 \mu \mathrm{m}$ sterile membrane filters. The residue was collected and re-used for the next washing. One hundred milliliters of DI water was again mixed with the residue and shaken for 24 hours at $120 \mathrm{rpm}$. These series of mixing and filtration steps were repeated six times for each solid-liquid ratio. All filtrates collected were acidified $(\mathrm{pH}<2)$ and stored at $6^{0} \mathrm{C}$ prior to the chemical analyses.

\subsection{Chemical analysis}

Concentrations of As, B, Se and coexisting ions greater than $0.1 \mathrm{mg} / \mathrm{L}$ were analyzed using the standard method of an inductively coupled plasma atomic emission spectrometer (ICP-AES) (ICPE-9000, Shimadzu Corporation, Japan). Leachates with low concentrations of As and Se $(<0.1 \mathrm{mg} / \mathrm{L})$ were pre-treated prior to the analysis using the hydride generator attached to the ICP-AES. For the pre-treatment of As, $30 \mathrm{ml}$ of sample leachate was mixed with $15 \mathrm{ml}$ of $12 \mathrm{M}$ $\mathrm{HCl}, 2 \mathrm{ml}$ of $20 \%$ potassium iodide (KI) solution, $1 \mathrm{ml}$ of $10 \%$ ascorbic acid solution and diluted with DI water to $50 \mathrm{ml}$. On the other hand, pre-treatment procedure for Se is as follows:

i. One milliliter of $6 \mathrm{M} \mathrm{HNO}_{3}$ and $0.25 \mathrm{ml}$ of $8 \mathrm{M} \mathrm{H}_{2} \mathrm{SO}_{4}$ were mixed with $50 \mathrm{ml}$ of sample in a beaker. 
ii. The mixture was heated at $250^{\circ} \mathrm{C}$ until the residual volume of solution left was only a few milliliters. Around this time, white fumes were seen coming out of the beaker.

iii. As soon as these white fumes were observed, the beaker was removed from the hotplate and allowed to cool at room temperature for ca. 1 hour.

iv. After cooling, $10 \mathrm{ml}$ of $6 \mathrm{M} \mathrm{HCl}$ was added and the solution was heated at $100{ }^{0} \mathrm{C}$ for 5 minutes.

v. The solution was removed from the hotplate, allowed to cool at room temperature and diluted to $50 \mathrm{ml}$.

Concentrations of B and coexisting ions less than $0.1 \mathrm{mg} / \mathrm{L}$ were analyzed using the ultrasonic aerosol generator attached to the ICP-AES. Sulfur in the leachate was predominantly in the form of sulfate $\left(\mathrm{SO}_{4}{ }^{2-}\right)$ based on the results of anion chromatography (ICS - 1000, Dionex Corporation, USA), so for faster and easier determination of $\mathrm{SO}_{4}{ }^{2-}$, the ICP-AES was used. The standard ICPAES method has a margin of error of ca. 2 - 3\% while analyses using more sensitive hydride and ultrasonic aerosol generators have uncertainties of ca. $5 \%$. Concentrations of cations like $\mathrm{Ca}^{2+}$, $\mathrm{Na}^{+}$and $\mathrm{Mg}^{2+}$ were analyzed using a cation chromatograph, ICS - 90 (Dionex Corporation, USA).

\section{RESULTS}

\subsection{Chemical and mineralogical properties of the excavated rocks}

The chemical and mineralogical properties of the excavated rock samples are summarized in Tables 2 and 3, respectively. The rock sample from the $\mathrm{T}$ site has the highest As content amounting to $150 \mathrm{mg} / \mathrm{kg}$ while that from the $S$ site contains the least at $6.9 \mathrm{mg} / \mathrm{kg}$. The As content of the H sample, which is mostly composed of mudstone, is similar to the average As 
content of sedimentary rocks $(5-10 \mathrm{mg} / \mathrm{kg}$ ) (Webster 1999). In contrast, altered rocks except the S sample have higher than the average As content. Arsenic in the T sample is more than 100 times higher than the average As content of igneous rocks (1.5 mg/kg) (Ure and Berrow 1982) while that in the $\mathrm{N}$ sample is ca. 2 times higher than the average As content of sedimentary rocks. Boron is found in significant amounts only in samples of sedimentary origin (i.e., $\mathrm{S}, \mathrm{N}$ and $\mathrm{H}$ samples). The unaltered $\mathrm{H}$ sample has the highest B content amounting to $209 \mathrm{mg} / \mathrm{kg}$. In addition, only the S sample contains Se at $0.59 \mathrm{mg} / \mathrm{kg}$. All the rock samples are predominantly composed of quartz and/or plagioclase and minor or trace amounts of pyrite (Table 3). Both S and N samples have calcite as a minor mineral consistent with the significant $\mathrm{CaO}$ in Table 2. Koktaite, which is an ammonium-calcium sulfate mineral, was detected in the $\mathrm{H}$ sample in trace amounts.

The sequential extraction procedure used in this study grouped As and B into five fractions/phases. Four of these fractions/phases are unstable under various geochemical conditions encountered in the environment. The exchangeable fraction is easily mobilized with changes in the concentrations of coexisting ions that can affect sorption. Hazardous contaminants associated with carbonates are unstable under mildly acidic conditions, those found in the Fe-Mn fraction are released under reducing conditions, and those incorporated with sulfides/organic matter dissolve under oxidizing conditions. The crystalline/residual phase is stable under normal geochemical conditions found in the environment, and hazardous elements associated in this fraction/phase are generally regarded as immobile. Majority of As found in the altered excavated rock samples (i.e., S, T and $\mathrm{N}$ samples) were associated with sulfides/organic matter and exchangeable phases/fractions amounting to at least $47 \%$ of the total As content (Figure 1). However, As in the carbonate phase of the T sample was significantly lower than those of the $\mathrm{S}$ and $\mathrm{N}$ samples. In contrast, ca. $73 \%$ of the total As content of the unaltered rock sample (i.e., $\mathrm{H}$ 
sample) was found together with the exchangeable, carbonates and sulfides/organic matter fractions. These results suggest that As in the rock, whether altered or unaltered, is mostly associated with the "mobile" phase susceptible to mobilization under normal geochemical conditions encountered in the environment. In contrast, B in the excavated rocks was mostly incorporated in the crystalline/residual fraction (39-56\%) (Figure 2). In the mobile fraction, B is found mostly with the exchangeable phase $(23-30 \%)$ and with sulfides/organic matter fraction $(10-14 \%)$. In all rock samples, amounts of As and B associated with Fe-Mn oxides were also significant except for the T sample (Figures 1 and 2).

\subsection{Effects of pH on As, B and Se leaching}

Figure 3 illustrates the leaching behaviors of As, B and Se from the S sample as a function of $\mathrm{pH}$. The leaching of As was highly $\mathrm{pH}$ dependent and was enhanced under both acidic and alkaline conditions. This As leaching trend with $\mathrm{pH}$ is identical to the previous results of the authors using altered rocks from different tunnel projects (Tabelin and Igarashi 2009). In contrast, Se leaching slightly increased at acidic $\mathrm{pH}$ but not in the alkaline region while the leaching behavior of B appeared to be independent of $\mathrm{pH}$. For the $\mathrm{S}$ sample, Se and B concentrations in the entire $\mathrm{pH}$ range were higher than the drinking water standards of Japan (Se: $10 \mu \mathrm{g} / \mathrm{L} ; \mathrm{B}: 1 \mathrm{mg} / \mathrm{L})$ while As release was only a problem at acidic and alkaline conditions.

\subsection{Effects of consecutive washing on leachate concentrations of As, B, Se and coexisting ions}

\subsubsection{S sample}

Properties of the leachates from the $\mathrm{S}$ sample are shown in Figure 4. The $\mathrm{pH}$ of this sample was slightly alkaline when in contact with water independent of the number of extractions and the solid-liquid ratio (Figure 4a). The leaching of As had a slight decreasing trend in all solid-liquid 
ratios used (Figure 4b), but As concentration was successfully lowered below $10 \mu \mathrm{g} / \mathrm{L}$ only at the lowest solid-liquid ratio of 1:10. Concentration of B had a decreasing trend as a function of the number of extraction, but the decrease was more dramatic compared to As regardless of the solid-liquid ratio (Figure 4c). Initially, B concentrations were 3.15, 2.05 and $1.35 \mathrm{mg} / \mathrm{L}$ for solidliquid ratios of 1:2, 1:5 and 1:10, respectively. After the sixth extraction, these values were lowered below ca. $0.5 \mathrm{mg} / \mathrm{L}$. It was also observed that B concentrations in the leachate were lower than the drinking water standard after several extractions depending on the solid-liquid ratio. The leaching curves of Se had a generally decreasing trend similar to those of As and B (Figure 4d). Selenium concentrations during the first extraction were significant in all the solidliquid ratios used and a maximum concentration of $117 \mu \mathrm{g} / \mathrm{L}$ was measured in the 1:2 solidliquid ratio. However, the concentration of Se in the leachate was lowered below $10 \mu \mathrm{g} / \mathrm{L}$ after only 2 extractions for the 1:5 and 1:10 solid-liquid ratios while one more additional extraction was necessary for the 1:2 ratio to achieve a similar result. Concentrations of $\mathrm{Fe}, \mathrm{Cl}^{-}$and $\mathrm{SO}_{4}{ }^{2-}$ in the leachate decreased with the number of extraction and were lower in cases with lower solidliquid ratios (Figures 4e, $\mathrm{g}$ and h). At higher solid-liquid ratios (i.e., 1:2 and 1:5), $\mathrm{Ca}^{2+}$ concentration decreased as the number of extraction increased, but was not observed in the lowest solid-liquid ratio of 1:10 (Figure 4f). The concentrations of As, B and Se had strong correlations with that of $\mathrm{SO}_{4}{ }^{2-}$ (Table 4). Additionally, moderate positive correlations were found between the concentrations of $\mathrm{B}$ and Se with that of $\mathrm{Cl}^{-}$, but only a weak positive correlation existed between As and $\mathrm{Cl}^{-}$(Table 4). Regardless of the solid-liquid ratio, the S sample continued to have significant $\mathrm{Ca}^{2+}$ and $\mathrm{SO}_{4}{ }^{2-}$ concentrations in the leachate even after the $6^{\text {th }}$ extraction most likely due to the continued dissolution of calcite and oxidation of pyrite found in the rock (Figures $4 f$ and $h$ ). 


\subsubsection{T sample}

Figure 5 shows the leachate chemistry of the T sample as functions of the solid-liquid ratio and the number of extraction. The leachate $\mathrm{pH}$ of this sample was acidic independent of the solidliquid ratio and the number of extraction (Figure 5a). Concentrations of As in the leachate were very high especially during the first extraction in the highest solid-liquid ratio of 1:2 (5,040 $\mu \mathrm{g} / \mathrm{L})$. Lowering the solid-liquid ratios to $1: 5$ and 1:10 dramatically decreased the concentrations of As to 1,540 and $262 \mu \mathrm{g} / \mathrm{L}$, respectively. In addition, As concentration also decreased substantially with increasing number of extraction dropping below $10 \mu \mathrm{g} / \mathrm{L}$ after the second extraction. After the sixth extraction, As concentrations in the leachate were ca. $1 \mu \mathrm{g} / \mathrm{L}$ in all cases. The concentration curves of coexisting ions like $\mathrm{Al}, \mathrm{Fe}, \mathrm{Ca}^{2+}, \mathrm{Mg}^{2+}, \mathrm{Cl}^{-}$and $\mathrm{SO}_{4}{ }^{2-}$ had similar flushing-out trends, that is, their concentrations were high at the start followed by significant concentration decrease with increasing number of extraction (Figures 5c, d, e, f, g and h). Among these above mentioned coexisting ions, $\mathrm{Al}, \mathrm{Fe}$ and $\mathrm{SO}_{4}{ }^{2-}$ concentrations were relatively high especially during the first two extractions regardless of the solid-liquid ratio used (Al: $\left.3-221 \mathrm{mg} / \mathrm{L} ; \mathrm{Fe}: 29-1980 \mathrm{mg} / \mathrm{L} ; \mathrm{SO}_{4}{ }^{2-}: 82-4260 \mathrm{mg} / \mathrm{L}\right)$. In addition, $\mathrm{SO}_{4}{ }^{2-}$ concentrations approached $10 \mathrm{mg} / \mathrm{L}$ similar to that observed in the $\mathrm{S}$ sample. Strong positive correlation between $\mathrm{As}$ and $\mathrm{SO}_{4}{ }^{2-}$ was also observed in this sample regardless of the solid-liquid ratio (Table 5). Concentrations of $\mathrm{Ca}^{2+}, \mathrm{Mg}^{2+}$ and $\mathrm{Cl}^{-}$were relatively low $\left(\mathrm{Ca}^{2+}: 0.01-10.1\right.$ $\left.\mathrm{mg} / \mathrm{L} ; \mathrm{Cl}^{-}: 1.36-3.02 \mathrm{mg} / \mathrm{L} ; \mathrm{Mg}^{2+}: 0.004-2.24 \mathrm{mg} / \mathrm{L}\right)$ in the leachate independent of the number of extraction. Regardless of these differences, lowering the solid-liquid ratio generally decreased the concentrations of these coexisting ions. These results indicate that the dissolution of soluble mineral phases and dilution have strong effects on the relative concentrations of coexisting ions in this sample. 


\subsubsection{N sample}

The $\mathrm{pH}$ values of the leachates from the $\mathrm{N}$ sample were slightly alkaline $(8.11-8.37)$ as illustrated in Figure 6a. In this sample, the leaching curve of As slightly decreased with increasing number of extraction and at lower solid-liquid ratio, but the concentrations were all above $10 \mu \mathrm{g} / \mathrm{L}$ (Figure 6b). In contrast, B curves resembled flushing-out trends similar to those observed with B and Se from the S sample (Figure 6c; Figures 4c and d). Concentrations of Al and Fe were relatively low in this sample (Al: $1.29-1.72 \mathrm{mg} / \mathrm{L} ; \mathrm{Fe}: 0.04-0.175 \mathrm{mg} / \mathrm{L})$, and both ions showed slight concentration variations with the number of extraction and solid-liquid ratio (Figures $6 \mathrm{~d}$ and e). On the other hand, the other coexisting ions like $\mathrm{Ca}^{2+}, \mathrm{Cl}^{-}$and $\mathrm{SO}_{4}{ }^{2-}$ had flushing-out leaching trends as a function of the number of extraction, and the concentrations of these ions decreased in accordance with as the solid-liquid ratio (Figures 6f, $g$ and $h$ ). The concentrations of As and $\mathrm{B}$ in this sample also had strong positive correlations with that of $\mathrm{SO}_{4}{ }^{2-}$ while moderate positive correlation was found between $\mathrm{B}$ and $\mathrm{Cl}^{-}$(Table 6).

\subsubsection{H sample}

The chemical properties of the leachate from the $\mathrm{H}$ sample are displayed in Figure 7 . The $\mathrm{pH}$ of this rock when in contact with water was also slightly alkaline similar to those of the $\mathrm{S}$ and $\mathrm{N}$ samples, but the $\mathrm{pH}$ values in this sample had slightly higher variations as a function of the number of extraction (Figure 7a). Concentration curves of As also had slightly decreasing trends similar to those of the $\mathrm{S}$ and $\mathrm{N}$ samples regardless of the solid-liquid ratio (Figure $7 \mathrm{~b}$ ). In this sample, the concentration of As decreased below $10 \mu \mathrm{g} / \mathrm{L}$ after ca. the sixth and fifth extraction for lower solid-liquid ratios of 1:5 and 1:10, respectively, but not in the highest solid-liquid ratio (1:2). In contrast, B concentration curves had typical flushing-out trends in all solid-liquid ratios 
utilized (Figure 7c). Initial B concentrations in the leachates were 2.98, 5.2 and $9.33 \mathrm{mg} / \mathrm{L}$ for solid-liquid ratios of 1:10, 1:5 and 1:2, respectively, which were higher than the drinking water standard of $1 \mathrm{mg} / \mathrm{L}$. However, these concentrations decreased dramatically with the number of extraction, and finally dropped below $1 \mathrm{mg} / \mathrm{L}$ after the sixth extraction even in the highest solidliquid ratio of 1:2. Coexisting ions like Fe were relatively low in the leachate (Figure 7d). On the other hand, relatively high concentrations of $\mathrm{Ca}^{2+}, \mathrm{Na}^{+}, \mathrm{Cl}^{-}$and $\mathrm{SO}_{4}{ }^{2-}$ were observed in the leachate especially during the first three extractions and at higher solid-liquid ratios. The leaching curves of $\mathrm{Ca}^{2+}, \mathrm{Na}^{+}$and $\mathrm{Cl}^{-}$also had flushing-out trends similar to B (Figures 7c, e, f and g). Similar to the other samples of sedimentary origin (i.e., $\mathrm{S}$ and $\mathrm{N}$ samples), concentrations of As and $\mathrm{B}$ had strong positive correlations with $\mathrm{SO}_{4}{ }^{2-}$ while $\mathrm{B}$ had moderate positive correlation with $\mathrm{Cl}^{-}$(Table 7).

\section{Discussion}

\subsection{Dissolution, dilution, oxidation and $p H$ variation}

The release of As from excavated rocks is affected by many factors and governed by complex processes. In altered rocks, the leaching of As is highly $\mathrm{pH}$ dependent and minor minerals like calcite and pyrite predominantly control the $\mathrm{pH}$ of the rock-water system (Tabelin and Igarashi 2009; Tabelin et al. 2010; Tabelin et al. 2012a; Tabelin et al. 2012b). The acidic leachate of the T sample could be attributed to the higher pyrite content of the rock relative to calcite. Oxidation of pyrite produces acidity as explained by the following equations:

$$
\begin{aligned}
& \mathrm{FeS}_{2(\mathrm{~s})}+3.5 \mathrm{O}_{2(\mathrm{aq})}+\mathrm{H}_{2} \mathrm{O} \longrightarrow \mathrm{Fe}^{2+}+2 \mathrm{H}^{+}+2 \mathrm{SO}_{4}^{2-} \quad \text { Equation } 1 \\
& \mathrm{FeS}_{2(\mathrm{~s})}+14 \mathrm{Fe}^{3+}+8 \mathrm{H}_{2} \mathrm{O} \longrightarrow 15 \mathrm{Fe}^{2+}+2 \mathrm{SO}_{4}{ }^{2-}+16 \mathrm{H}^{+} \quad \text { Equation } 2
\end{aligned}
$$


In addition, leachates during the first couple of extractions were more acidic because of the partial oxidation of the T sample prior to sampling. Partial oxidation (i.e., atmospheric oxidation) of pyrite results in the formation of sulfuric acid and other soluble phases such as $\mathrm{Fe}^{2+}$-sulfates, the former being formed due to the hygroscopic nature of $\mathrm{Fe}^{2+}$-sulfates (Jerz and Rimstidt, 2004). Because of the low buffering capacity of the rock in the absence of minerals like calcite, the $\mathrm{pH}$ of the rock-water system would remain acidic for a very long time. On the other hand, the $\mathrm{S}$ and $\mathrm{N}$ samples have higher contents of calcite relative to pyrite. Thus, although pyrite oxidation also occurred in these samples, the abundant calcite in the rock effectively buffered the $\mathrm{pH}$ resulting in the slightly alkaline $\mathrm{pH}$ of the leachates. In the case of the $\mathrm{H}$ sample, koktaite was the source of the $\mathrm{NH}_{4}{ }^{+}$ions that buffered the acidity produced by pyrite oxidation.

The concentrations of As in the leachate from the rock samples of sedimentary origin (i.e., S, $\mathrm{N}$ and $\mathrm{H}$ samples) were generally lower compared to the $\mathrm{T}$ sample primarily because of the relatively higher As content of this altered volcanic rock (ca. $7-20$ times higher than the samples of sedimentary origin). In all the rock samples, addition of more water (i.e., lower solidliquid ratio) diluted the concentration of As resulting in its proportional decrease in the leachate. However, the leaching of As as a function of the number of extraction was different in the $\mathrm{T}$ sample compared to the rest of the excavated rocks. Arsenic concentration in the $\mathrm{T}$ sample had a distinct flushing-out trend which was not apparent in the other rock samples. In other words, As from the $\mathrm{T}$ sample behaved more conservatively than those of the other rock samples. These differences could be attributed to the $\mathrm{pH}$ of the rock-water system and its complex interactions with the different As-bearing solid phases of the rock. In the T sample, acidic $\mathrm{pH}$ of the leachate resulted in the higher mobility of As (Figure 3) as well as more rapid dissolution of As-bearing soluble minerals (Figures $5 \mathrm{~d}$ and $\mathrm{h}$ ). In addition, the acidic $\mathrm{pH}$ prevented the precipitation of 
dissolved $\mathrm{Fe}$ as Fe oxyhydroxides/oxides, which could effectively reduce the concentration of As in the leachate through adsorption and co-precipitation (Dzombak and Morel, 1990; Jang and Dempsey, 2008). In contrast, As in the samples of sedimentary origin (i.e., S, N and H samples) has low mobility because of the slightly alkaline $\mathrm{pH}$ that enhances adsorption (Tabelin and Igarashi 2009).

Because the T sample has very little organic carbon content, majority of the As associated with the sulfides/organic matter phase is in sulfide minerals like pyrite. In addition, majority of the exchangeable As fraction in this sample may have been formed due to the atmospheric oxidation of pyrite in the rock prior to sampling (Tabelin et al. 2012a; Tabelin et al. 2012b). Thus, the release of As from the T sample during the first couple of extraction was probably controlled by the dissolution of As-rich soluble phases like Fe-sulfates and amorphous Fe oxyhydroxides, resulting in the observed flushing-out As concentration trend. After most of these soluble As-bearing phases had been dissolved, the rock continued to release As, albeit at lower concentrations, because of the continued oxidation of pyrite found in the rock. These deductions are supported not only by the similar flushing-out trends of $\mathrm{Fe}$ and $\mathrm{SO}_{4}{ }^{2-}$ but also of the strong positive correlations between $\mathrm{As}$ and $\mathrm{SO}_{4}{ }^{2-}$ concentrations in the leachate regardless of the solidliquid ratio.

The mobilization of As in the $\mathrm{S}, \mathrm{N}$ and $\mathrm{H}$ samples is most probably controlled by the combined effects of dissolution of soluble minerals, oxidation of pyrite, neutralization of calcite/koktaite and adsorption/desorption of As onto minerals found in the rock like Fe/Al oxyhydroxides/oxides and clay minerals. The oxidation of pyrite and the continued dissolution of calcite in these samples were evident in the significant concentrations of $\mathrm{Ca}^{2+}$ and $\mathrm{SO}_{4}{ }^{2-}$ even after repetitive washing (Figures 4, 6 and 7). Furthermore, strong positive correlations between 
As and $\mathrm{SO}_{4}{ }^{2-}$ support the importance of pyrite oxidation and the dissolution of soluble phases like Fe-sulfates in the release of As from these rocks (Tables 4, 5, 6 and 7). In addition, the mobility of As in these samples was strongly influenced by the availability of adsorbents like Fe/Al oxyhydroxides and clay minerals. Based on previously published works, the movement of As in a system is substantially retarded because of its strong adsorption affinity to $\mathrm{Fe} / \mathrm{Al}$ oxyhydroxides/oxides and clay minerals like kaoliniteits (Cornelis et al. 2008; Dousova et al. 2003; Dzombak and Morel 1990; Gosh and Teoh 1985; Lin and Puls 2000; Wang and Mulligan 2006).

Boron and Se had strong positive correlations with $\mathrm{SO}_{4}{ }^{2-}$ similar to As, which suggests that the mechanisms controlling the release of these elements from the excavated rocks are identical. However, discrepancies between the leaching behaviors of $\mathrm{B}$ and $\mathrm{Se}$ as functions of $\mathrm{pH}$ and number of extraction and those of As may imply that B and Se behave more conservatively than As. This means that B and Se are not easily affected by co-precipitation and/or adsorption reactions. In addition, moderate positive correlations of $\mathrm{B}$ and Se concentrations to the $\mathrm{Cl}^{-}$ concentration indicate that flushing-out of diagenetic sea water from the excavated rock of sedimentary origin is an important release mechanism of B and Se (Tables 4, 6 and 7). These deductions are supported by the less $\mathrm{pH}$-dependent behaviors of $\mathrm{B}$ and Se compared to As, their flushing-out leaching trends and their association with phases that dissolve easily. Additionally, the effects of dilution were more pronounced on the leachate concentrations of B and Se than As. Coexisting ions like $\mathrm{Ca}^{2+}, \mathrm{Na}^{+}, \mathrm{Cl}^{-}$and $\mathrm{SO}_{4}{ }^{2-}$ generally had flushing-out trends, and were also strongly influenced by dilution. The concentrations of $\mathrm{Na}^{+}$and $\mathrm{Cl}^{-}$in the $\mathrm{H}$ sample were significantly higher than the other samples and could be attributed to the pre-existing geological condition during its deposition. This sample is mudstone and most of the cations and anions 
found in this rock may have come from the sea during its diagenesis (Figure 7). In addition, dramatically higher $\mathrm{B}$ concentration in the leachate of the $\mathrm{H}$ sample in comparison to the other samples probably comes from the flushed-out diagenetic sea water retained in this sedimentary rock.

\subsection{Engineering implications}

Removal of hazardous elements using the consecutive washing technique employed in this study was promising especially for the removal of B and Se from excavated rocks, but was less effective when applied to As. Oxyhydroxides/oxides of $\mathrm{Fe}$ and $\mathrm{Al}$ as well as clay minerals found in the excavated rock partly retarded the leaching of As, but were not enough to lower its concentration down to the environmentally acceptable level. Moreover, majority of As in these rocks were found with sulfides/organic matter, which indicates that the rock could continue to release considerable amounts of As as long as available sulfide minerals continue to oxidize. Therefore, it is important to combine other mitigation techniques to address the problem associated with excavated rocks especially in cases where the rock contains several hazardous elements with different leaching properties. For example, it is possible to apply the washing technique as a preliminary step to remove more soluble hazardous elements like B and Se. This would then be followed by mitigation techniques like adsorption and neutralization to address the problem associated with the acidic leachate $\mathrm{pH}$ and As.

\section{CONCLUSIONS}

Tunnel construction projects in Japan continue to excavate large volumes of rocks that are problematic because of their significantly high contents of hazardous contaminants like As, B, Se and heavy metals. Arsenic in the rock was found mostly with the sulfides/organic matter fraction 
while B and Se were mostly associated with the more soluble phases. Variations in the $\mathrm{pH}$ of the rock-water system dramatically changed the leaching behavior of As, but was not observed in those of B and Se. The release of As from the excavated rocks was controlled by dissolution of soluble phases in the first couple of washing steps and by pyrite oxidation and adsorption/desorption later on. On the other hand, B and Se were removed by the combined flushing-out of diagenetic sea water and dissolution of soluble phases. Increasing the number of extraction after the removal of majority of these soluble phases had little effect on the concentrations of B and Se in the leachate. The six-step washing technique effectively removed most of the B and Se contents of the excavated rocks because both of these elements were less affected by the $\mathrm{pH}$ and were mostly associated with the soluble phases. However, removal of As from the rock using the same technique was ineffective because this element had a more complex pH-dependent leaching behavior than those of $\mathrm{B}$ and $\mathrm{Se}$, and was mostly associated with the sulfides/organic matter fraction that dissolves at kinetically slower rates.

\section{Acknowledgments}

A part of this study was financially supported by the Japan Society for the Promotion of Science (JSPS) grant-in-aid for scientific research. The authors also wish to thank the anonymous reviewers for their valuable inputs to this paper.

\section{References}

Acharyya, S.K., Lahiri, S., Raymahashay, B.C., Bhowmik, A. (2000). Arsenic toxicity of groundwater in parts of the Bengal basin in India and Bangladesh: The role of Quarternary stratigraphy and Holecene sea-level fluctuation. Environmental Geology, 39(10), 1127-1137.

Aiuppa, A., Avino, R., Brusca, L., Caliro, S., Chiodini, G., D’Alessadro, W., Favara, R., Federico, C., Ginevra, W., Inguaggiato, S., Longo, M., Pecoraino, G., Valenza, M. (2006). 
Mineral control of arsenic content in thermal waters from volcano-hosted hydrothermal systems: Insights from the island of Ischia and Phlegrean Fields. Chemical Geology, 229, 313 - 330.

Akai, J., Izumi, K., Fukuhara, H., Masuda, H., Nakano, S., Yoshimura, T., Ohfuji, H., Anwar, H.M., Akai, K. (2004). Mineralogical and geomicrobial investigations on groundwater arsenic enrichment in Bangladesh. Applied Geochemistry, 19, 215-230.

Allen, K.D., Hahn, G.A. (1994). Geology of Sunbeam and Grouse Creek gold-silver deposits, Yankee Fork mining district, Eocene Challis volcanic field, Idaho: A volcanic dome and volcaniclastic-hosted epithermal system. Econ. Geol., 89, 1964-1982.

Brannon, J.M., Patrick, W.H. (1987). Fixation, transformation and mobilization of arsenic in sediments, Environ. Sci. Technol., 21, 450-459.

Clevenger, T.E. (1990). Use of sequential extraction to evaluate the heavy metals in mining wastes. Water, Air and Soil Pollution, 50, 241-253.

Cornelis, G., Anette-Johnson, C., Van Gerven, T., Vandecasteele, C. (2008). Leaching mechanisms of oxyanionic metalloid and metal species in alkaline solid wastes: A review. Applied Geochemistry, 23, 955-976.

Das, D., Samanta, S., Mandal, B.K., Chowdhury, T.R., Chanda, C.R., Chowdry, P.P., Basu, G.K., Chakraborti, D. (1996). Arsenic in groundwater in six districts of West Bengal, India. Environmental Geochemistry and Health, 18, 5-15.

Dousova, B., Machovic, V., Kolousek, D., Kovanda, F., Dornicak, V. (2003). Sorption of As (V) species from aqueous solution. Water, Air, and Soil Pollution, 149, 251-267.

Dowling, C.B., Poreda, R.J., Basu, A.R., Peters, S.L., Aggarwal, P.K. (2002). Geochemical study of arsenic release mechanisms in the Bengal Basin groundwater. Water Resources Research, 38(9), 1173.

Dzombak, D.A., Morel, F.M.M. (1990). Surface Complexation Modeling: Hydrous Ferric Oxide. New York: John Wiley and Sons. 
Fail, P.A., Chapin, R.E., Price, C.J., Heindel, J.J. (1998). General, reproductive, developmental, and endocrine toxicity of boronated compounds. Reproductive Toxicology Review, 12(1), 1-18.

Fishbein, L. (1983). Environmental selenium and its significance. Fundamental Applied Toxicology, 3, 411-419.

Ghosh, M.M., Teoh, R.S. (1985). Adsorption of arsenic on hydrous aluminum oxide. In: Proceedings of the Seventh Mid-Atlantic Industrial Waste Conference, Lancaster, PA, pp. 139155.

Halbach, P., Pracejus, B., Marten, A. (1993). Geology and mineralogy of massive sulfide ores from Okinawa trough, Japan. Econ. Geol., 88, 2210-2225.

Horton, T.W., Becker, J.A., Craw, D., Koons, P.O., Page Chamberlain, C. (2001). Hydrothermal arsenic enrichment in an active mountain belt: Southern Alps, New Zealand. Chemical Geology, $177,323-339$.

Huston, D.L., Sie, S.H., Sauter, G.F., Cook, D.R., Both, R.A. (1995). Trace elements in sulfide minerals from eastern Australian volcanic-hosted massive sulfide deposits: Part 1. Proton microprobe analyses of pyrite, chalcopyrite and sphalerite, and Part 2. Selenium levels in pyrite: Comparison with $\delta^{34} \mathrm{~S}$ values and implications for the source of sulfur in volcanogenic hydrothermal systems. Econ. Geol., 90, 1167-1196.

Jang, J.H., Dempsey, B.A. (2008). Coadsorption of arsenic(III) and arsenic(V) onto hydrous ferric oxide: Effects of abiotic oxidation of arsenic(III), extraction efficiency, and model accuracy. Environ. Sci. Technol., 42, 2893-2898.

Jerz, J.K., Rimstidt, J.D. (2004). Pyrite oxidation in moist air. Geochem. Cosmochim. Acta, 68, 701-714.

Levinson, A.A., Ludwick, J.C. (1966). Speculation on the incorporation of boron into argillaceous sediments. Geochem. Cosmochim. Acta, 30, 855-861. 
Lin, Z., Puls, R.W. (2000). Adsorption, desorption and oxidation of arsenic affected by clay minerals and aging process. Environmental Geology, 39(7), 753-759.

Marumo, K., Ebashi, T., Ujiie, T. (2003). Heavy metal concentrations, leachabilities and lead isotope ratios of Japanese soils. Shigen - Chishitsu, 53(2), 125-146. (Paper in Japanese with English abstract)

O’Day, P.A., Vlassopoulos, D., Root, R., Rivera, N. (2004). The influence of sulfur and iron on dissolved arsenic concentrations in the shallow subsurface under changing redox conditions. Proceedings of the National Academy of Sciences, 101 (38), 13703-13708.

Ostwald, J., England, B.M. (1977). Notes on framboidal pyrite from Allandale, New South Wales, Australia. Mineral. Deposita, 12, 111-116.

Parks, J.L., Edwards, M. (2009). Boron in the environment. Critical Reviews in Environmental Science and Technology, 35(2), 81-114.

Peters, S.C., Blum, J.D. (2003). The source and transport of arsenic in a bedrock aquifer, New Hampshire, USA, Applied Geochemistry, 18, 1773-1787.

Savage, K.S., Tingle, T.N., O’Day, P.A., Waychunas, G.A., Bird, D.K. (2000). Arsenic speciation in pyrite and secondary weathering phases, Mother Lode Gold District, Tuolumne County, California, Applied Geochemistry, 15, 1219-1244.

Sengupta, A.K. (2002). Environmental Separation of Heavy Metals - Engineering Processes. London: Lewis Publishers.

Tabelin, C.B., Igarashi, T. (2009). Mechanisms of arsenic and lead release from hydrothermally altered rock. Journal of Hazardous Materials, 169, 980-990.

Tabelin, C.B., Igarashi, T., Tamoto, S. (2010). Factors affecting arsenic mobility from hydrothermally altered rock in impoundment-type in situ experiments. Minerals Engineering, 23, 238-248. 
Tabelin, C.B., Igarashi, I., Takahashi, R. (2012a). The roles of pyrite and calcite in the mobilization of arsenic from hydrothermally altered rocks excavated in Hokkaido, Japan. Journal of Geochemical Exploration, under review.

Tabelin, C.B., Igarashi, I., Takahashi, R. (2012b). Mobilization and speciation of arsenic and lead from hydrothermally altered rock in column experiments under ambient conditions. Applied Geochemistry 27, 326-342.

Tessier, A., Campbell, G.C., Bisson, M. (1979). Sequential extraction procedure for the speciation of particulate trace metals. Analytical Chemistry, 51, $844-850$.

Tinggi, U. (2003). Essentiality and toxicity of selenium and its status in Australia: A review. Toxicology Letters, 137, 103-110.

Ure, A., Berrow, M. (1982). Chapter 3: The elemental constituents of soils. In: Bowen, H.J.M., (Ed.), Environmental Chemistry (pp. 94-203). London: Royal Society of Chemistry.

Wang, S., Mulligan, C. (2006). Natural attenuation processes for remediation of arsenic contaminated soils and groundwater. Journal of Hazardous Materials, 138(3), 459-470.

Webster, J.G. (1999). Arsenic. In: Marshall, C.P., Fairbridge, R.W. (Ed), Encyclopaedia of Geochemistry (pp. 21-22). London: Chapman Hall.

Zawislanski, P.T., Benson, S.M., Terberg, R., Borglin, S.E. (2003). Selenium speciation, solubility and mobility in land-disposed dredge sediments. Environ. Sci. Technol., 37, 24152420. 


\section{Figure Captions}

FIGURE 1 Sequential extraction results for As (expressed as the fraction of solid-phase metal solubilized in each solution). Numbers printed in italics below each rock sample label represent the total As content in each sample in $\mathrm{mg} / \mathrm{kg}$.

FIGURE 2 Sequential extraction results for B (expressed as the fraction of solid-phase metal solubilized in each solution). Numbers printed in italics below each rock sample label represent the total B content in each sample in $\mathrm{mg} / \mathrm{kg}$.

FIGURE 3 Concentrations of As, B and Se in the leachate of the S sample as a function of $\mathrm{pH}$.

FIGURE 4 Effects of solid-liquid ratio and frequency of washing on the leachate chemistry of the S sample; (a) pH change with the number of extraction, (b) As concentration change with the number of extraction, (c) B concentration change with the number of extraction, (d) Se concentration change with the number of extraction, (e) Fe concentration change with the number of extraction, (f) $\mathrm{Ca}^{2+}$ concentration change with the number of extraction, $(\mathrm{g}) \mathrm{Cl}^{-}$concentration change with the number of extraction, and (h) $\mathrm{SO}_{4}{ }^{2-}$ concentration change with the number of extraction.

FIGURE 5 Effects of solid-liquid ratio and frequency of washing on the leachate chemistry of the T sample; (a) pH change with the number of extraction, (b) As concentration change with the number of extraction, (c) Al concentration change with the number of extraction, (d) Fe concentration change with the number of extraction, (e) $\mathrm{Ca}^{2+}$ concentration change with the number of extraction, (f) $\mathrm{Mg}^{2+}$ concentration change with the number of extraction, $(\mathrm{g}) \mathrm{Cl}^{-}$concentration change with the number of extraction, and (h) $\mathrm{SO}_{4}{ }^{2-}$ concentration change with the number of extraction. 
FIGURE 6 Effects of solid-liquid ratio and frequency of washing on the leachate chemistry of the $\mathrm{N}$ sample; (a) $\mathrm{pH}$ change with the number of extraction, (b) As concentration change with the number of extraction, (c) B concentration change with the number of extraction, (d) Fe concentration change with the number of extraction, (e) $\mathrm{Al}$ concentration change with the number of extraction, (f) $\mathrm{Ca}^{2+}$ concentration change with the number of extraction, (g) $\mathrm{Cl}^{-}$concentration change with the number of extraction, and (h) $\mathrm{SO}_{4}{ }^{2-}$ concentration change with the number of extraction.

FIGURE 7 Effects of solid-liquid ratio and frequency of washing on the leachate chemistry of the $\mathrm{H}$ sample; (a) $\mathrm{pH}$ change with the number of extraction, (b) As concentration change with the number of extraction, (c) B concentration change with the number of extraction, (d) Fe concentration change with the number of extraction, (e) $\mathrm{Ca}^{2+}$ concentration change with the number of extraction, (f) $\mathrm{Na}^{+}$concentration change with the number of extraction, $(\mathrm{g}) \mathrm{Cl}^{-}$concentration change with the number of extraction, and (h) $\mathrm{SO}_{4}{ }^{2-}$ concentration change with the number of extraction. 


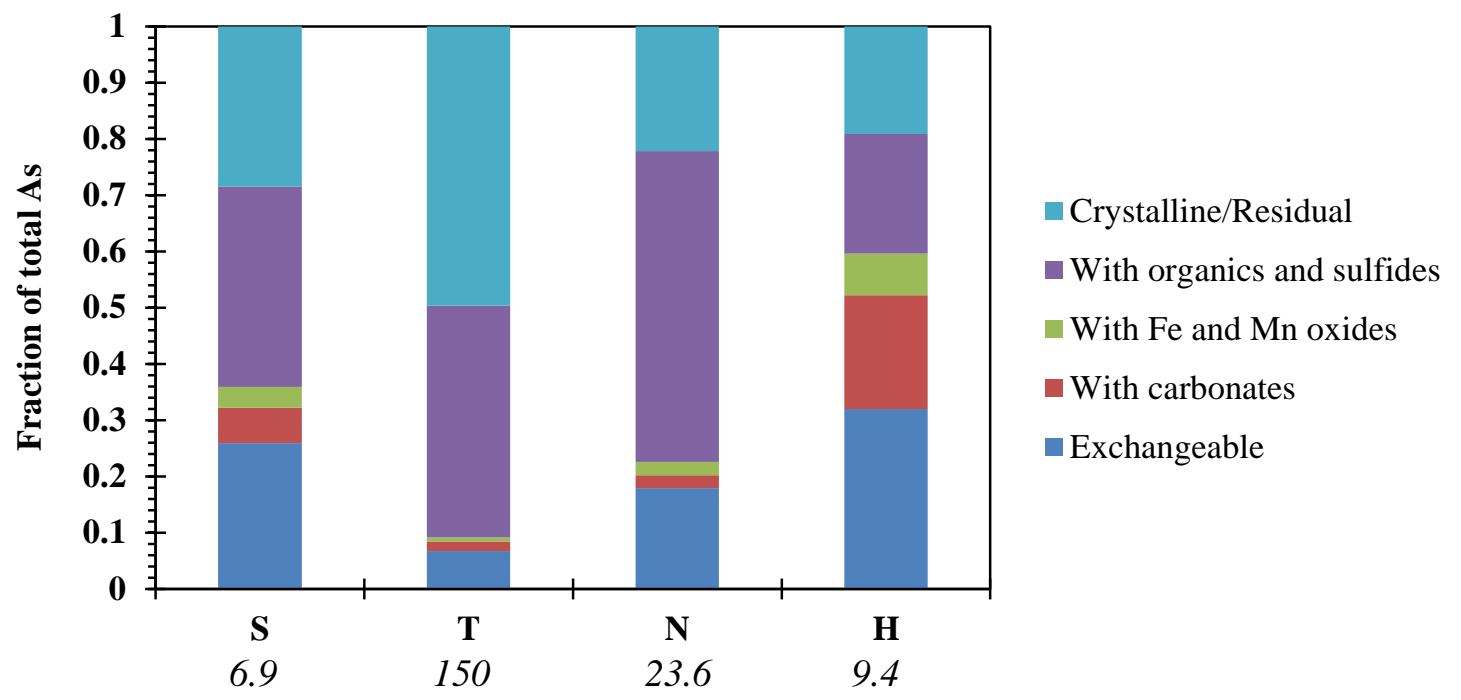

Excavated rock sample

Total As content $(\mathrm{mg} / \mathrm{kg}$ )

Figure 1

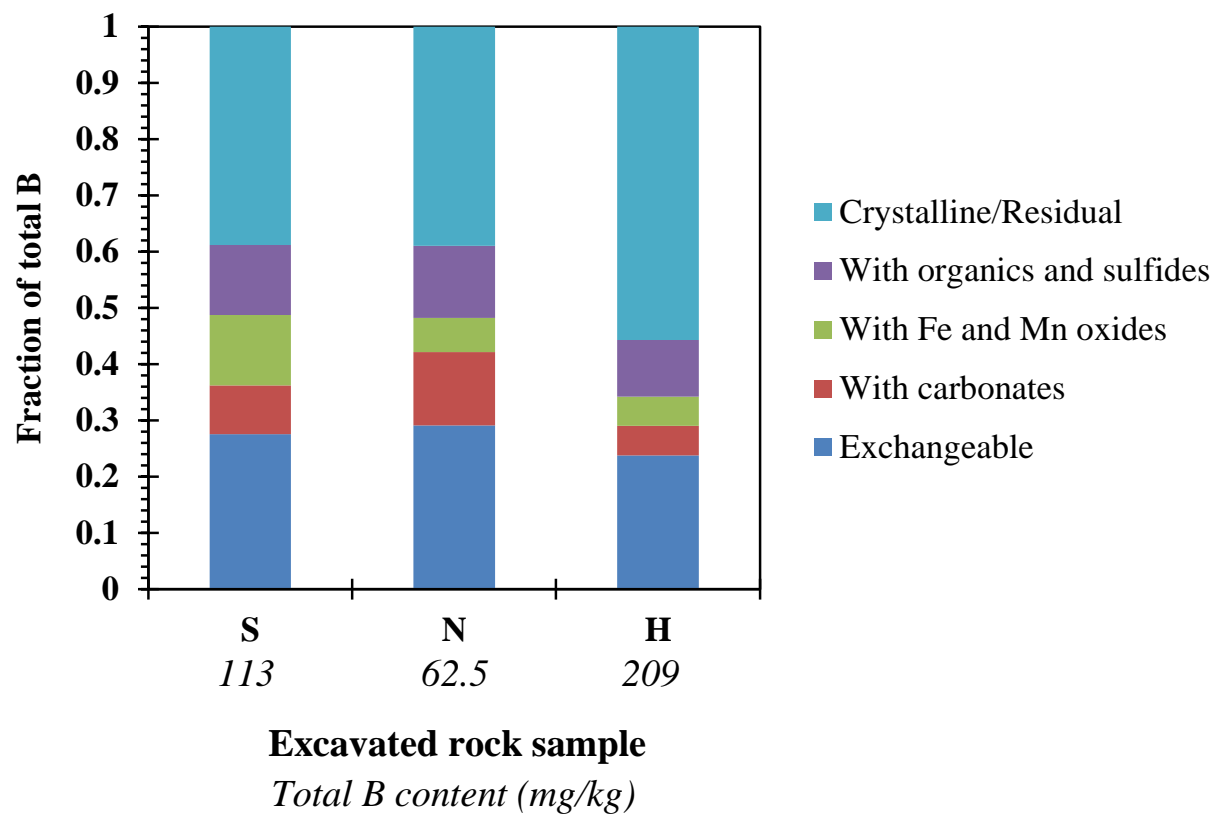

Figure 2 


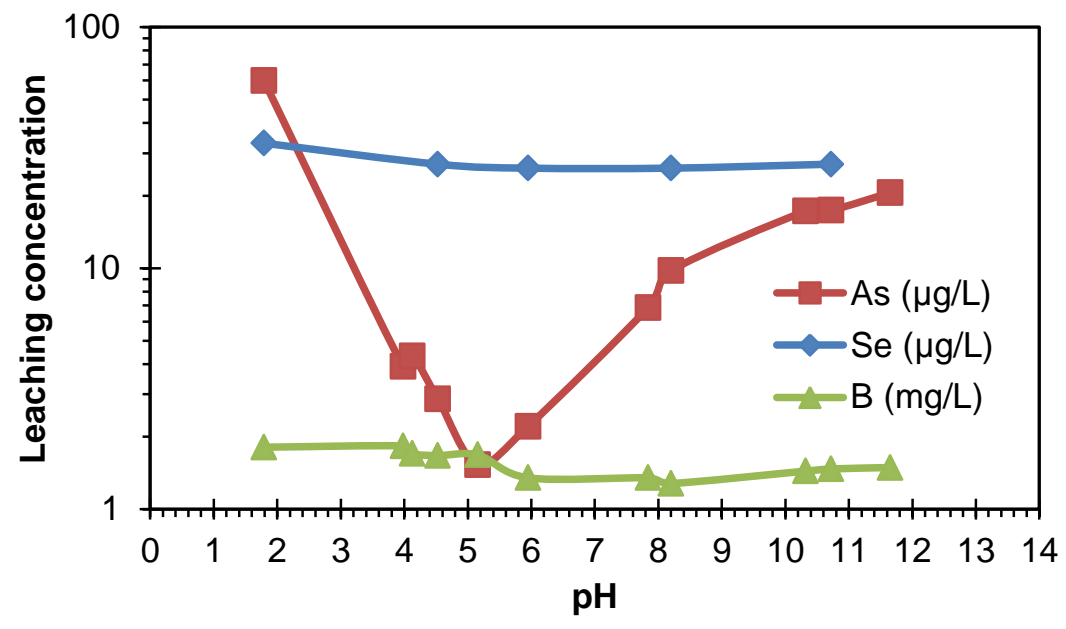

Figure 3 

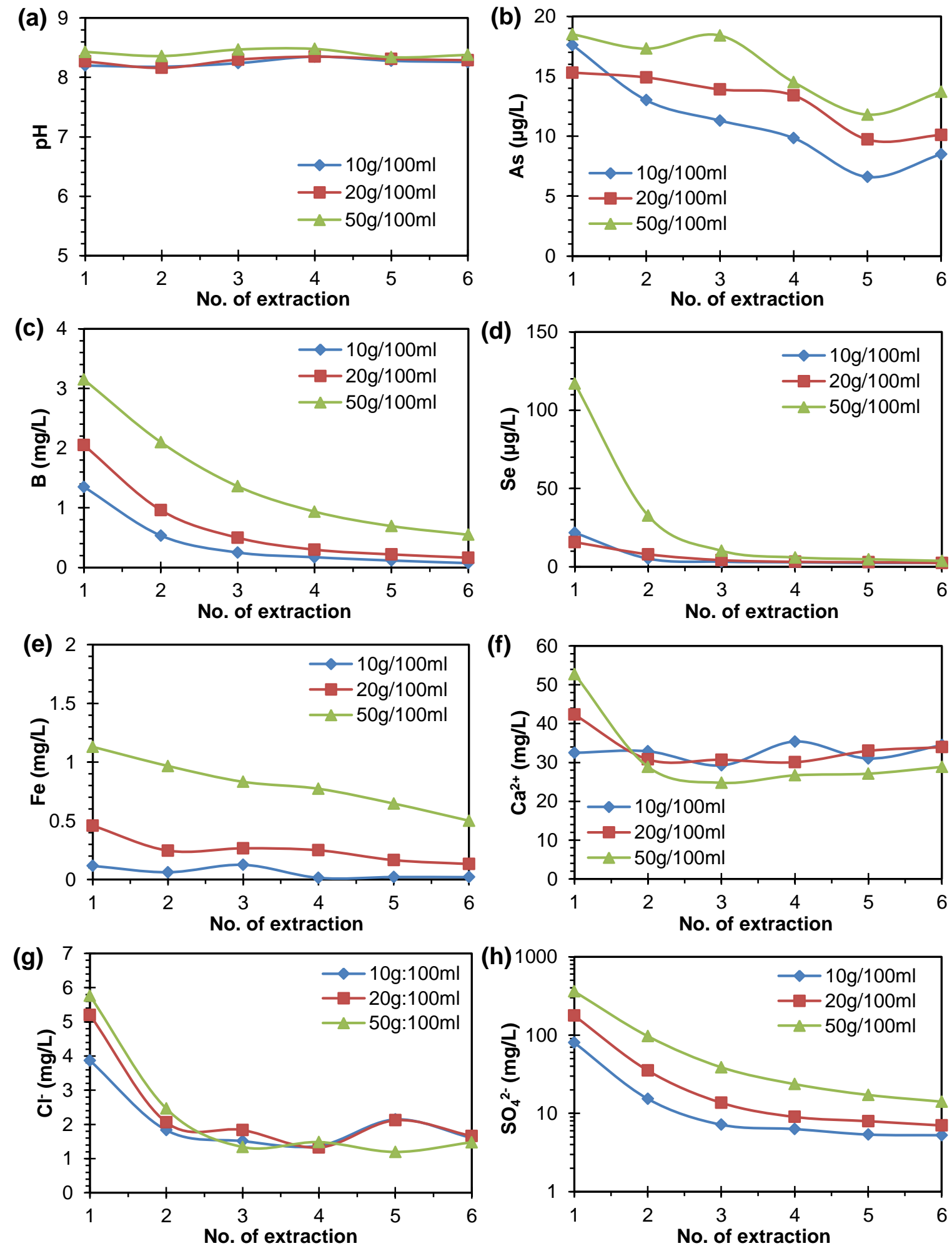

Figure 4 
(a)
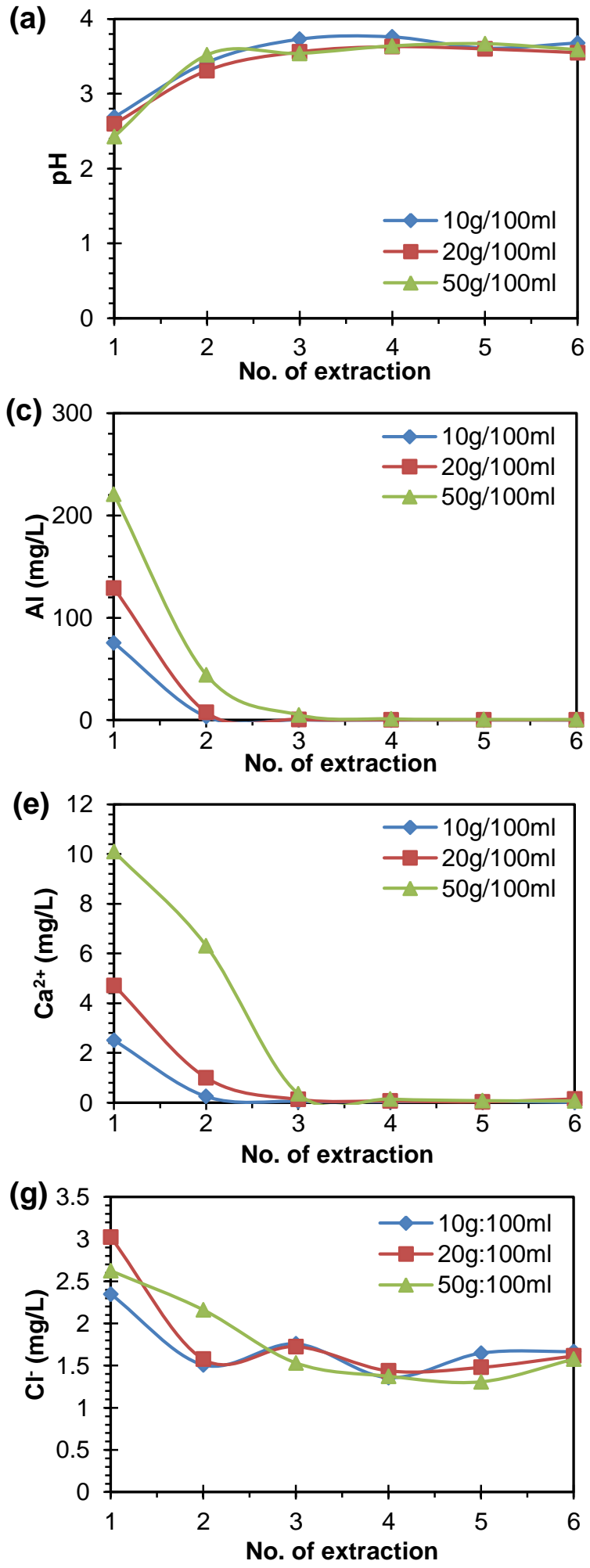
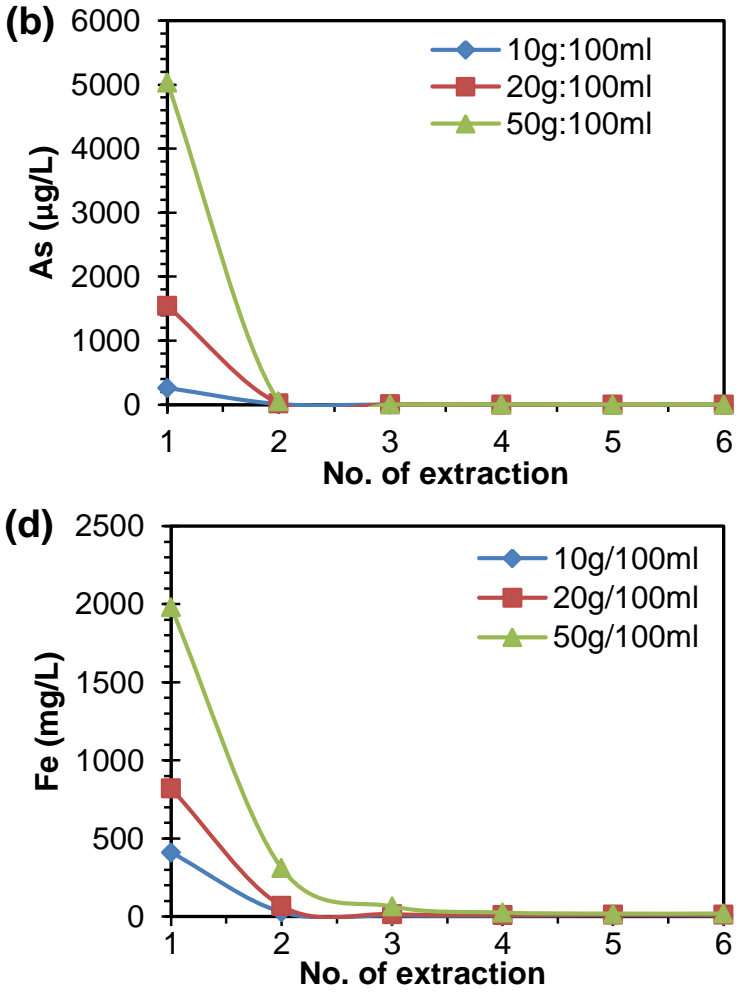

(f)
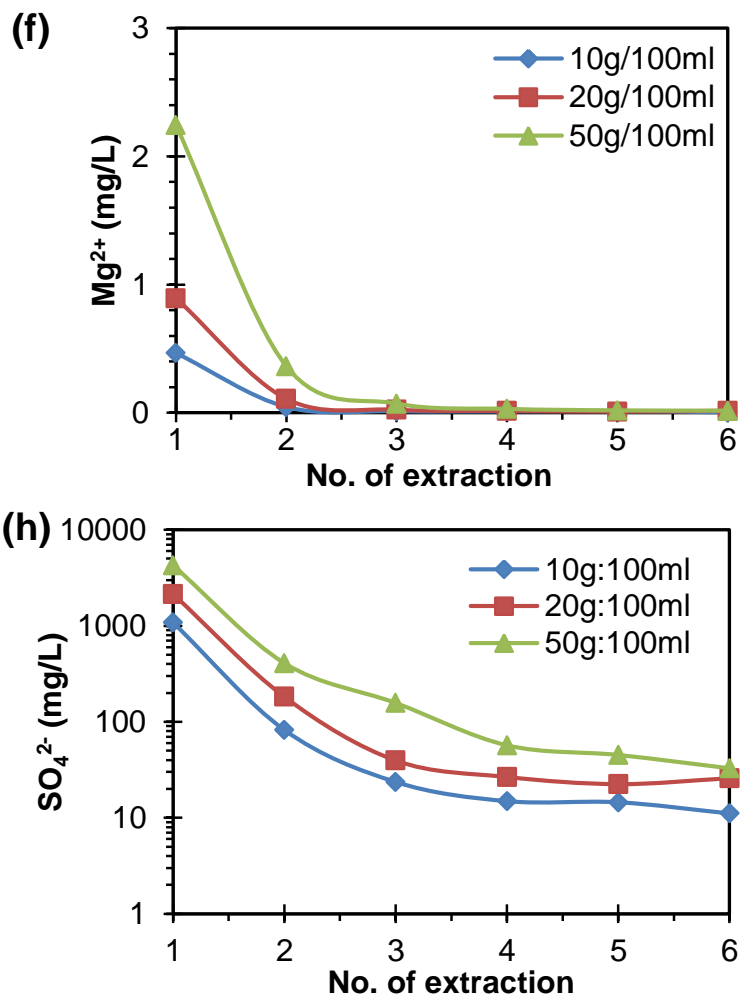

Figure 5 
(a)

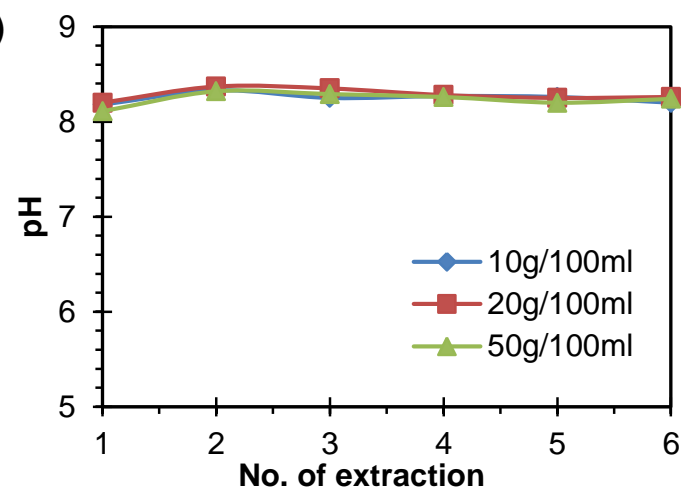

(c)

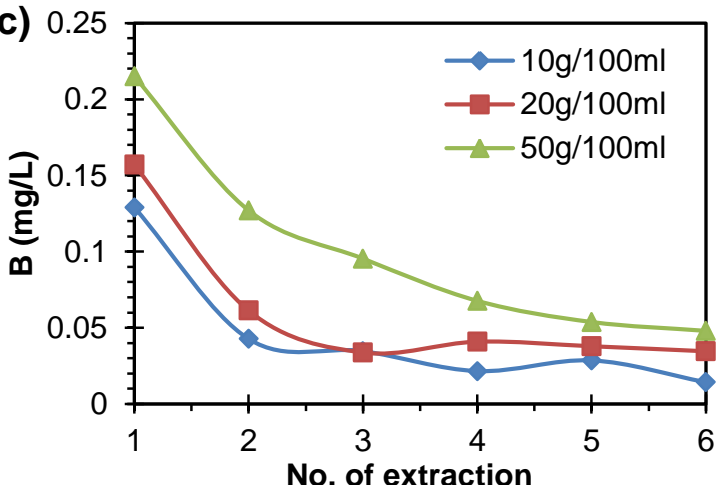

(e)

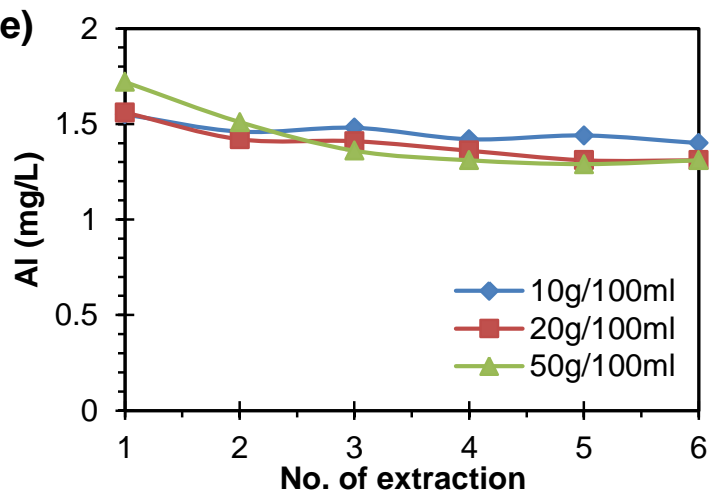

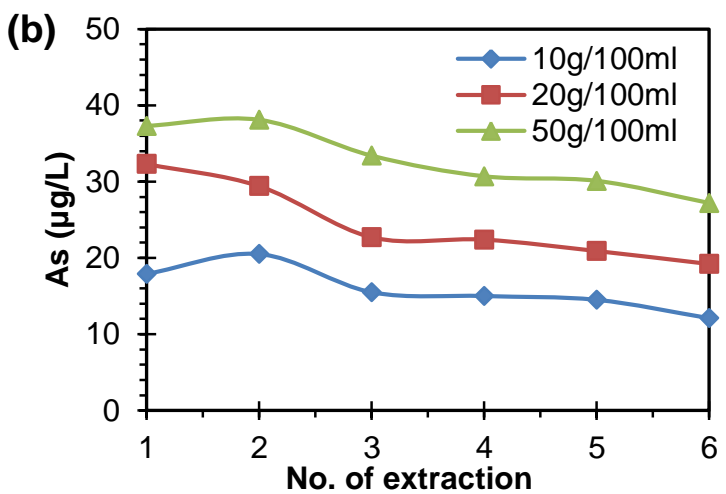

(d)

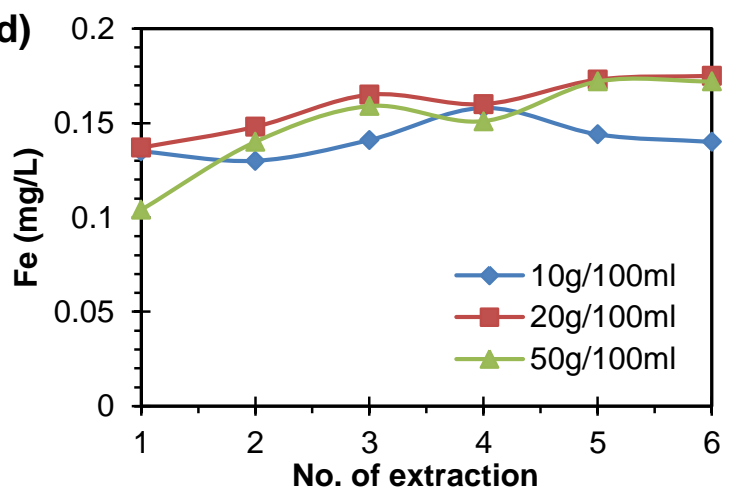

(f)

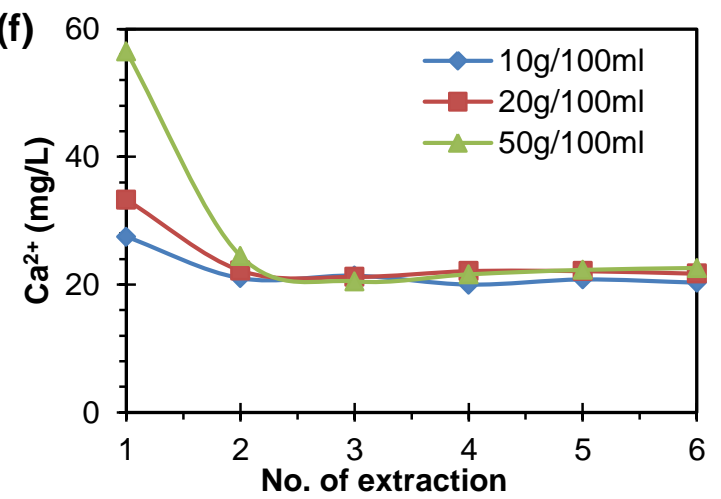

(h) 1000

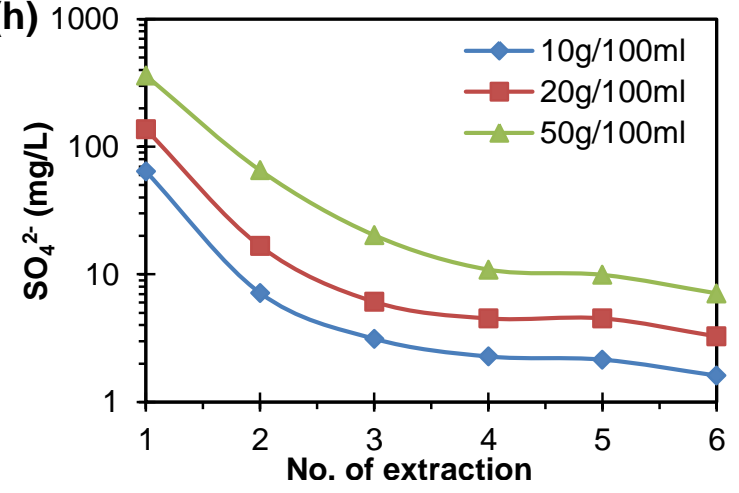

Figure 6 
(a)

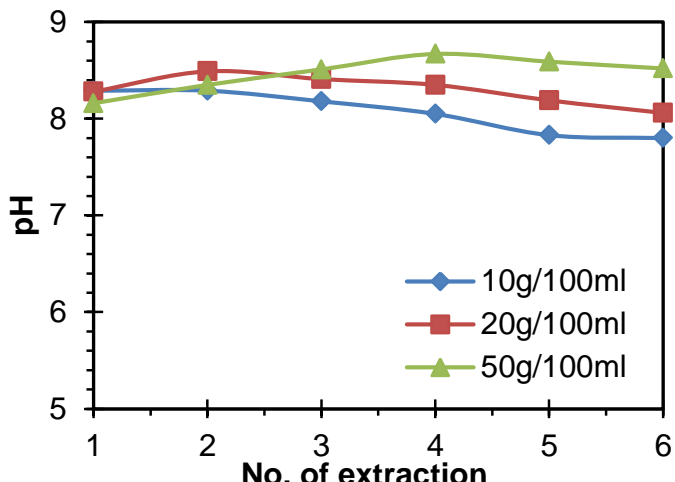

(c)

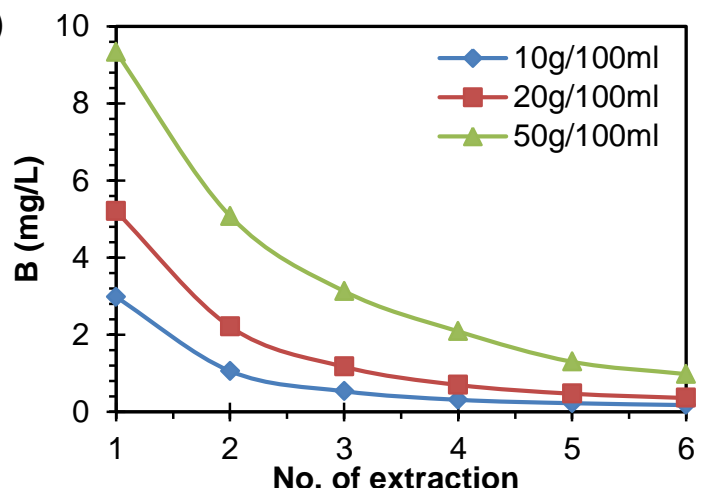

(e)

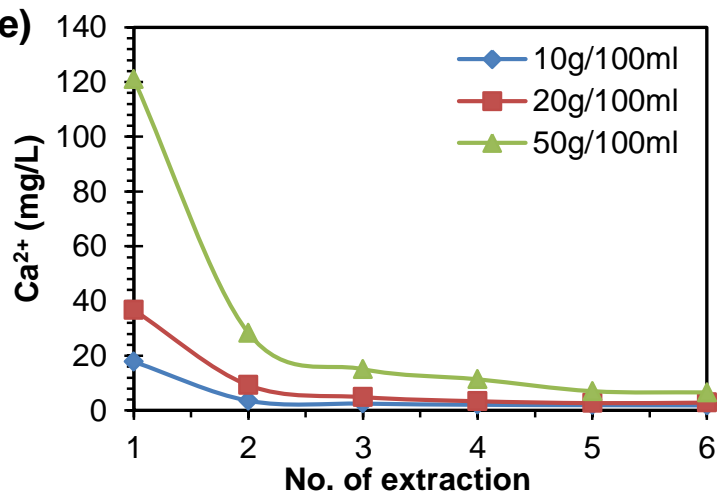

(g)

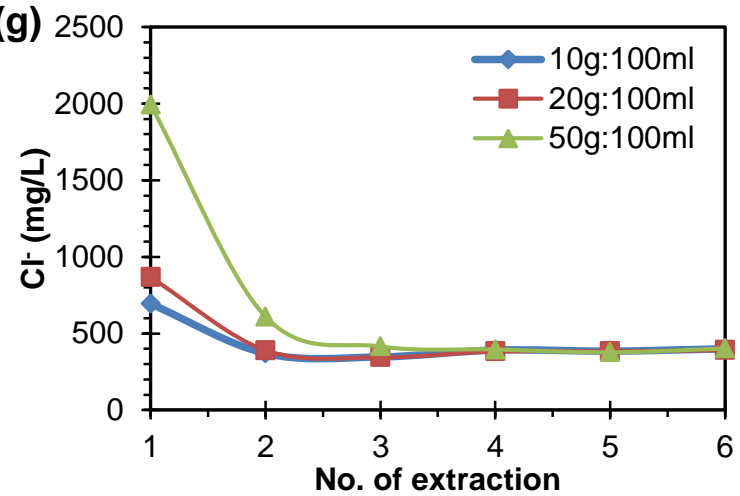

(b)

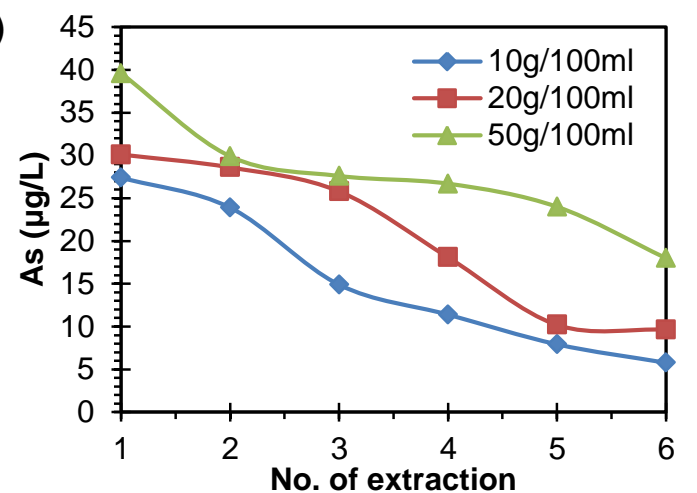

(d)

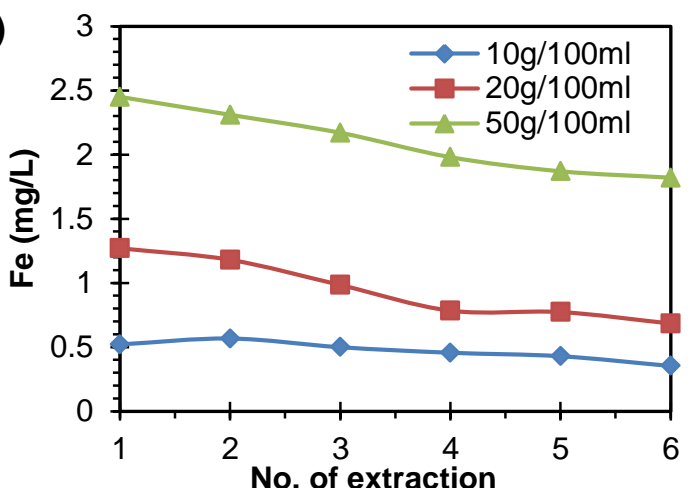

(f)

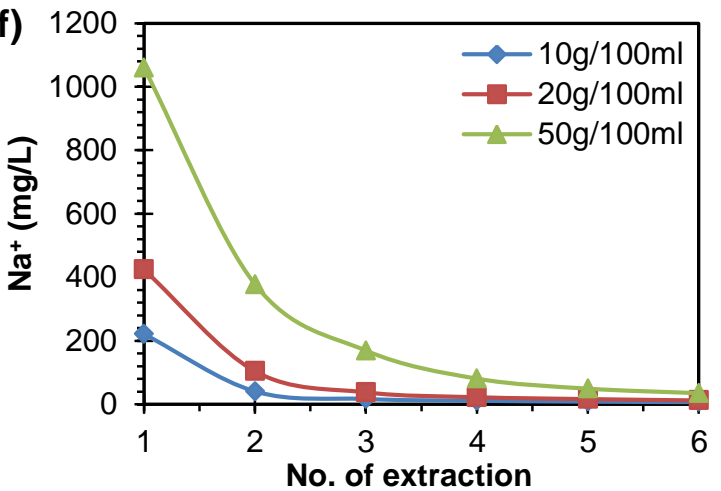

(h) 10000

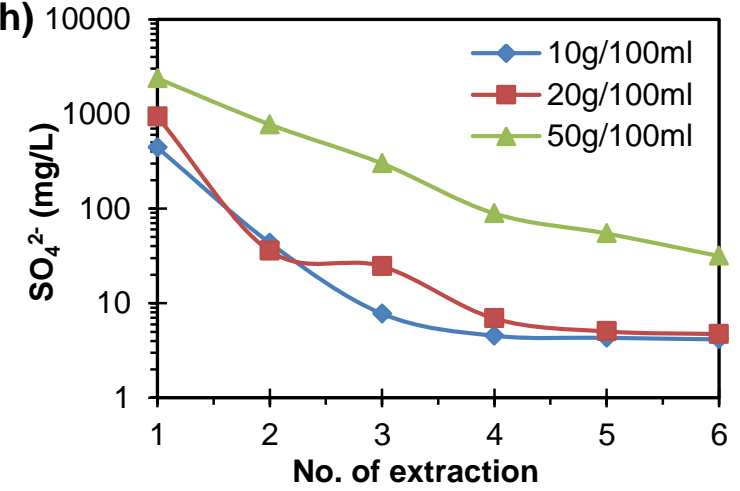

Figure 7 
Table 1. Sequential extraction for arsenic speciation

\begin{tabular}{|c|c|c|c|c|c|c|c|}
\hline Step & Extractant & $\mathrm{pH}$ & $\begin{array}{l}\text { Liquid } \\
\text { to solid } \\
\text { ratio } \\
(\mathrm{ml} / \mathrm{g}) \\
\end{array}$ & $\begin{array}{l}\text { Temperature } \\
\qquad\left({ }^{0} \mathrm{C}\right)\end{array}$ & $\begin{array}{l}\text { Duration } \\
\text { (h) }\end{array}$ & $\begin{array}{l}\text { Mixing } \\
\text { speed } \\
(\mathrm{rpm})\end{array}$ & Extracted phase \\
\hline 1 & $1 \mathrm{M} \mathrm{NaH}_{2} \mathrm{PO}_{4}$ & 5 & $20 / 1$ & 25 & 1 & 120 & Exchangeable \\
\hline 2 & $1 \mathrm{M} \mathrm{CH}_{3} \mathrm{COONa}$ & 5 & $20 / 1$ & 25 & 5 & 120 & Carbonates \\
\hline 3 & $\begin{array}{l}0.04 \mathrm{M} \mathrm{NH}_{2} \mathrm{OH} . \mathrm{HCl} \text { in } 25 \% \text { acetic } \\
\text { acid }\end{array}$ & - & $20 / 1$ & 50 & 5 & 120 & Fe-Mn oxides \\
\hline 4 & $\begin{array}{l}0.04 \mathrm{M} \mathrm{NH} \mathrm{NH}_{2} \mathrm{OH} . \mathrm{HCl} \text { in } 25 \% \text { acetic } \\
\text { acid; } 30 \% \mathrm{H}_{2} \mathrm{O}_{2} ; 0.02 \mathrm{M} \mathrm{HNO}_{3}\end{array}$ & - & $36 / 1$ & 50 & 5 & 120 & $\begin{array}{l}\text { Sulfides and } \\
\text { organic matter }\end{array}$ \\
\hline 5 & \multicolumn{6}{|c|}{ Calculated } & Residual \\
\hline
\end{tabular}

Table 2. Chemical composition of excavated rock samples used in the experiments

\begin{tabular}{cccccccccccc}
\hline Sample & $\begin{array}{c}\mathrm{SiO}_{2} \\
(\mathrm{wt} \%)\end{array}$ & $\begin{array}{c}\mathrm{Al}_{2} \mathrm{O}_{3} \\
(\mathrm{wt} \%)\end{array}$ & $\begin{array}{c}\mathrm{Fe}_{2} \mathrm{O}_{3} \\
(\mathrm{wt} \%)\end{array}$ & $\begin{array}{c}\mathrm{MgO} \\
(\mathrm{wt} \%)\end{array}$ & $\begin{array}{c}\mathrm{CaO} \\
(\mathrm{wt} \%)\end{array}$ & $\begin{array}{c}\mathrm{Na}_{2} \mathrm{O} \\
(\mathrm{wt} \%)\end{array}$ & $\begin{array}{c}\mathrm{K}_{2} \mathrm{O} \\
(\mathrm{wt} \%)\end{array}$ & $\begin{array}{c}\mathrm{S} \\
(\mathrm{wt} \%)\end{array}$ & $\begin{array}{c}\mathrm{As} \\
(\mathrm{mg} / \mathrm{kg})\end{array}$ & $\begin{array}{c}\mathrm{B} \\
(\mathrm{mg} / \mathrm{kg})\end{array}$ & $\begin{array}{c}\mathrm{Se} \\
(\mathrm{mg} / \mathrm{kg})\end{array}$ \\
\hline $\mathrm{S}$ & 65.8 & 15 & 6.4 & 2.81 & 2.6 & 1.7 & 3.5 & 0.48 & 6.9 & 113 & 0.59 \\
$\mathrm{~T}$ & 63.3 & 6.88 & 16 & 0.05 & 0.05 & 0.01 & 0.1 & 10.6 & 150 & - & - \\
$\mathrm{N}$ & 58.7 & 14.4 & 6.22 & 3.49 & 3.31 & 1.31 & 3.22 & 0.2 & 23.6 & 62.5 & - \\
$\mathrm{H}$ & 82.6 & 7.86 & 3.91 & 1.72 & 0.86 & - & 2.06 & 2.16 & 9.4 & 209 & - \\
\hline
\end{tabular}

Table 3. Mineralogical composition of excavated rock samples determined using XRD

\begin{tabular}{ccccccccccc}
\hline Sample & Qz & Pl & Chl & Cal & Py & Kao & Gal & Bir & Mus & Kok \\
\hline $\mathrm{S}$ & +++ & ++ & + & + & - & & & & & \\
$\mathrm{T}$ & +++ & & & & + & - & - & - & & \\
$\mathrm{N}$ & +++ & ++ & - & + & - & - & & & - & \\
$\mathrm{H}$ & +++ & ++ & & & - & & & & & \\
\hline
\end{tabular}

+++: Major; ++: Moderate; +: Minor; -: Trace

Qz: Quartz; Pl: Plagioclase; Chl: Chlorite; Cal: Calcite; Py: Pyrite; Kao: Kaolinite; Gal: Galena; Bir: Birnessite;

Mus: Muscovite; Kok: Koktaite

*Note: In samples with little or no volcanic glass (e.g., sedimentary rocks), major, moderate, minor and trace roughly represent $>30 \%, 10-30 \%, 2-10 \%$ and $<2 \%$, respectively. 
Table 4. Correlation of $\mathrm{Cl}^{-}$and $\mathrm{SO}_{4}{ }^{2-}$ with As, $\mathrm{B}$ and Se in S sample

\begin{tabular}{cccc}
\hline Sample & $\alpha$ & $\beta$ & $\mathrm{R}$ \\
\hline $\mathrm{As} \mathrm{vs} \mathrm{SO}_{4}{ }^{2-}$ & 7.31 & 0.184 & 0.82 \\
$\mathrm{As} \mathrm{vs} \mathrm{Cl}^{-}$ & 10.8 & 0.236 & 0.38 \\
$\mathrm{~B} \mathrm{vs} \mathrm{SO}_{4}{ }^{2-}$ & 0.046 & 0.803 & 0.94 \\
$\mathrm{~B} \mathrm{vs} \mathrm{Cl}^{-}$ & 0.212 & 1.32 & 0.56 \\
$\mathrm{Se} \mathrm{vs} \mathrm{SO}_{4}{ }^{2-}$ & 0.557 & 0.805 & 0.96 \\
$\mathrm{Se} \mathrm{vs} \mathrm{Cl}^{-}$ & 0.426 & 0.932 & 0.76 \\
\hline $\mathrm{y}=\alpha x^{\beta}, \mathrm{y}: \mathrm{As}, \mathrm{B}_{\text {or Se concentration in the leachate, } \mathrm{x}: \mathrm{Cl}^{-} \text {or } \mathrm{SO}_{4}{ }^{2-}}$ \\
concentration in the leachate, $\alpha, \beta$ : constant, R: correlation coefficient
\end{tabular}

Table 5. Correlation of $\mathrm{SO}_{4}{ }^{2-}$ with As in $\mathrm{T}$ sample

\begin{tabular}{cccc}
\hline Sample & $\alpha$ & $\beta$ & $\mathrm{R}$ \\
\hline $\mathrm{As} \mathrm{vs} \mathrm{SO}_{4}{ }^{2-}$ & 0.021 & 1.38 & 0.97 \\
\hline
\end{tabular}

$\mathrm{y}=\alpha \mathrm{x}^{\beta}, \mathrm{y}:$ As concentration in the leachate, $\mathrm{x}: \mathrm{SO}_{4}{ }^{2-}$ concentration in the leachate, $\alpha, \beta$ : constant, R: correlation coefficient

Table 6. Correlation of $\mathrm{Cl}^{-}$and $\mathrm{SO}_{4}{ }^{2-}$ with $\mathrm{As}$ and $\mathrm{B}$ in N sample

\begin{tabular}{cccc}
\hline Sample & $\alpha$ & $\beta$ & $\mathrm{R}$ \\
\hline $\mathrm{As} \mathrm{vs} \mathrm{SO}{ }^{2-}$ & 15.4 & 0.171 & 0.75 \\
$\mathrm{As} \mathrm{vs} \mathrm{Cl}^{-}$ & 34.8 & 0.31 & 0.39 \\
$\mathrm{~B} \mathrm{vs} \mathrm{SO}_{4}{ }^{2-}$ & 0.018 & 0.457 & 0.97 \\
$\mathrm{~B} \mathrm{vs} \mathrm{Cl}^{-}$ & 0.208 & 1.02 & 0.64 \\
\hline
\end{tabular}

$\mathrm{y}=\alpha \mathrm{x}^{\beta}, \mathrm{y}:$ As or $\mathrm{B}$ concentration in the leachate, $\mathrm{x}: \mathrm{Cl}^{-}$or $\mathrm{SO}_{4}{ }^{2-}$ concentration in the leachate, $\alpha, \beta$ : constant, $\mathrm{R}$ : correlation coefficient

Table 7. Correlation of $\mathrm{Cl}^{-}$and $\mathrm{SO}_{4}{ }^{2-}$ with As and $\mathrm{B}$ in $\mathrm{H}$ sample

\begin{tabular}{cccc}
\hline Sample & $\alpha$ & $\beta$ & $\mathrm{R}$ \\
\hline $\mathrm{As} \mathrm{vs} \mathrm{SO}{ }^{2-}$ & 8.25 & 0.219 & 0.85 \\
$\mathrm{As} \mathrm{vs} \mathrm{Cl}$ & 0.432 & 0.612 & 0.49 \\
$\mathrm{~B} \mathrm{vs} \mathrm{SO}_{4}{ }^{2-}$ & 0.164 & 0.523 & 0.96 \\
$\mathrm{~B} \mathrm{vs} \mathrm{Cl}^{-}$ & 0.00002 & 1.81 & 0.69 \\
\hline $\begin{array}{l}\mathrm{y}=\alpha \mathrm{x}^{\beta}, \mathrm{y}: \text { As or B concentration in the leachate, } \mathrm{x:} \mathrm{Cl}^{-} \text {or } \mathrm{SO}_{4}{ }^{2-} \\
\text { concentration in the leachate, } \alpha, \beta: \text { constant, R: correlation coefficient }\end{array}$
\end{tabular}

